\title{
Tree Islands of the Florida Everglades- Long-Term Stability and Response to Hydrologic Change
}

Tree islands are important centers of biodiversity in the Florida Everglades; they have two to three times the plant and animal diversity of the surrounding wetlands. This high diversity is due primarily to their higher elevation relative to the adjacent wetlands (fig. 1). In the natural Everglades system, water levels fluctuated seasonally with rainfall, and tree islands were the only sites that escaped flooding during the wet season. These seasonally dry sites provided refugia and nesting sites for animals and allowed tree and shrub communities to flourish.

Major changes to the natural Everglades hydrology occurred after severe flooding from hurricanes in 1947 and 1948. As a result of those storms, millions of acres of land were under water for several months. Shortly thereafter, the Central and Southern Florida (C\&SF) Project for Flood Control was implemented to protect urban areas from flooding. Beginning in 1952, the C\&SF Project constructed three Water Conservation Areas (WCAs) that hold surface water to augment water supply in the east and to maintain water discharge to Everglades National Park in the south. Construction of the Water Conservation Areas resulted in hydrologic fragmentation of the greater Everglades ecosystem and disrupted seasonal freshwater flow through the system. Consequently, wading bird populations were reduced, and it is estimated that half the tree islands were lost or degraded.

In an effort to increase water supplies to restore the Everglades to a more natural state while still meeting other regional water needs, Congress authorized the Comprehensive Everglades Restoration Plan (CERP) in 2000. Research is underway to ensure that restoration targets reflect the natural predrainage hydrology and ecology.

Ongoing research by the U.S. Geological Survey (USGS) is documenting the distribution of predrainage wetland plant communities and their response to specific hydrologic and environmental

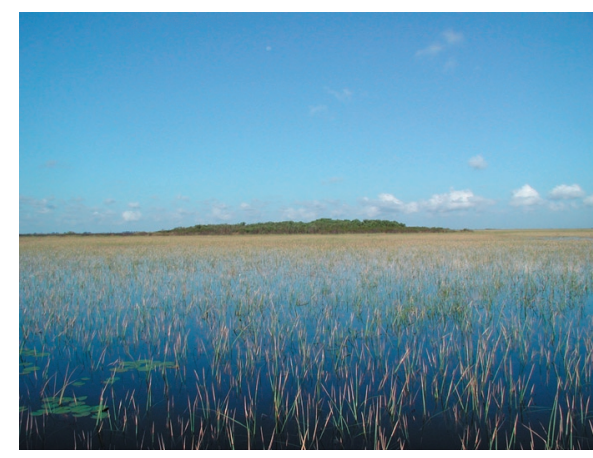

Figure 1. Fixed tree island in the central Everglades. Photograph by Debra A. Willard.

changes. Of particular interest are the long-term stability of tree islands and their tolerance for hydrologic variability. USGS researchers are using paleoecological techniques on tree islands throughout the Everglades to determine how long the tree islands have existed, to identify geological conditions necessary for tree-island formation, and to document changes in community composition through time. The resulting spatial and historical information will improve predictive models of ecosystem response to specific CERP implementation plans.

\section{Everglades Tree-Island Communities}

Tree islands consist of distinct clusters of trees, shrubs, and ferns interspersed throughout sawgrass marshes and waterlily sloughs of the Everglades landscape (fig. 2). Three types of tree islands occur in the Everglades (fig. 3): (1) fixed tree islands, (2) strand tree islands, and (3) pop-up, or battery, tree islands. These differ in community composition, distribution within the Everglades, and origin.

Fixed tree islands. - Fixed tree islands are teardrop shaped, and their long axis runs generally north to south, roughly parallel to flow. Many fixed tree islands developed over topographic highs in the underlying limestone. The head of the island overlies the highest point and is covered by semitropical hardwoods, upland plants that cannot tolerate prolonged flooding, and many ferns. The near tail of the tree island is directly downstream of the head and includes a community with dense ferns, shrubs, aquatic plants, and semitropical hardwoods that can tolerate limited flooding. The far tail contains a mixture of floodtolerant ferns, shrubs, sedges, and other marsh plants. Surrounding the entire tree island is a transitional zone with dense shrubs, ferns, and aquatic plants.

Strand tree islands. - Strand tree islands are elongate features found primarily in Arthur R. Loxahatchee National Wildlife Refuge (NWR). The central part of strand tree islands typically is dominated by dahoon holly and ferns and is flooded for short periods during the year. Their margins contain a mixture of shrubs and aquatic plants.

Pop-up, or battery, tree islands. Pop-up, or battery, tree islands are small, generally circular tree islands; they are very common in Loxahatchee NWR. Pop-up tree islands are co-dominated by red bay and dahoon holly trees and ferns.

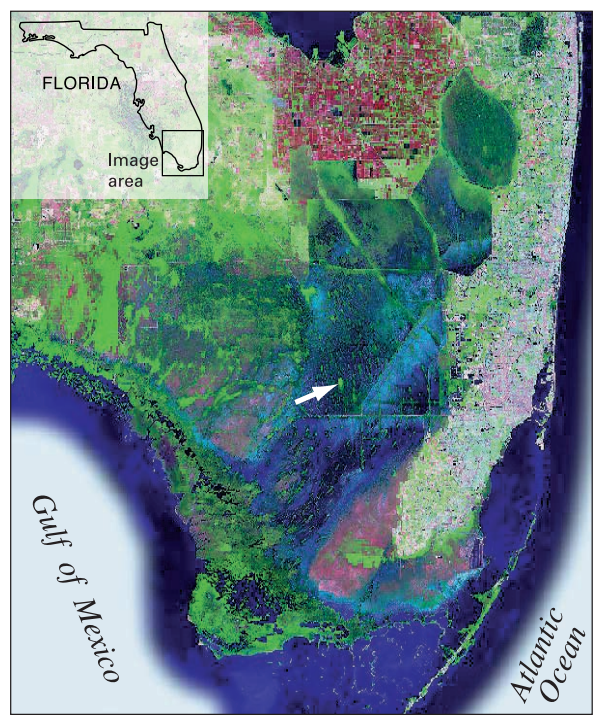

U.S. Geological Survey satellite image, 1993

Figure 2. Satellite image of the Florida Everglades. Tree islands are visible even in satellite imagery, and a very large tree island is marked by the arrow. 


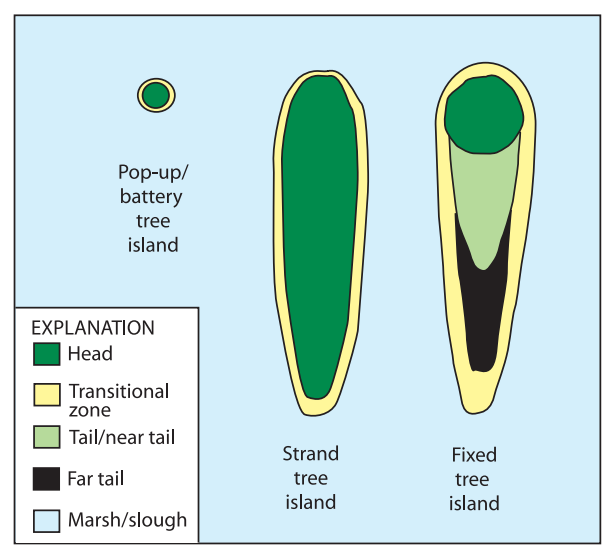

Figure 3. Graphic representation of three tree-island types in the Florida Everglades. Pop-up, or battery, tree islands are very small and have a narrow transition to the surrounding wetland. Strand tree islands are long and thin. They have relatively homogeneous woody vegetation on the head and a relatively narrow transitional zone. Fixed tree islands are teardrop shaped and have the tallest trees on the elevated head. Trees, shrubs, and flood-tolerant plants occupy the near tail, and shrubs, sawgrass, cattail, and other aquatic plants occur in the far tail. The entire tree island is surrounded by a relatively broad transitional zone.

In their margins, shrubs and ferns are common, and the entire tree island typically is surrounded by a narrow strip of dense sawgrass with abundant ferns.

\section{Everglades Tree-Island Pollen Assemblages}

Pollen deposited in Everglades sediments (fig. 4) typically is not transported far from the source plant communities, and at least 11 types of Everglades wetland are distinguishable by using pollen assemblages (Willard and others, 2001). In the pollen record, fixed tree islands are distinguished by high percentages of fern spores for two main reasons. First, ferns are the most common ground-cover plants on most tree islands. Second, the most common trees on tree islands are insect pollinated, and so their pollen is not readily dispersed to the atmosphere, and relatively little is available for preservation in the sediment.

Present-day strand and battery tree islands from Loxahatchee NWR differ from fixed tree islands in dominance of holly pollen. Analysis of pollen and spores from transects across the tree islands into the adjacent marsh indicates that pollen from tree-island taxa is rare in adjacent marshes. Abundant occurrence of treeisland pollen in samples from sediment cores can be used to identify the timing of tree-island formation and to identify changes in community composition.

\section{Analysis of Everglades Tree-Island Development}

Until recently, the timing and cause of tree-island formation have been poorly understood. Estimates of the timing of initial tree-island development originally ranged from several thousand years ago to as recently as the last few decades. To better understand the age and origins of these features and the response of tree-island communities to natural climate variability and historic hydrologic changes, sediment cores were collected on and around 29 tree islands throughout the Everglades (fig. 5). These cores were dated by using radioisotopic techniques, including carbon-14 dating, which provides reliable dates from $\sim 40,000$ to $\sim 300$ years ago, and lead-210 dating, which provides age models for the last century. These age models were paired with vegetational reconstruction based on pollen analysis from cores to identify the timing of tree-island formation and to determine tree-island response to hydrologic changes in the 20th century.

\section{Tree-Island Trends in the Northern Everglades}

The northeastern Everglades, including Loxahatchee NWR, contains the thickest and oldest peats of the Everglades. Dates from basal peat samples indicate that peat accumulation began as long as 6,000 calendar years before present (Gleason and Stone, 1994). Loxahatchee vegetation consists of a mixture of waterlily sloughs and sawgrass marshes with strand and battery tree islands scattered densely throughout. Ongoing USGS research in Loxahatchee NWR focuses on the strand islands that formed on shallow sites in a deeper marsh (Stone and others, 2002). Pollen assemblages indicate that tree-island taxa were established on some strand islands more than 1,100 years ago (fig. 5a); further sampling is necessary to determine how much earlier these features truly formed. All sites sampled indicate that holly did not become a dominant element in strand communities until the

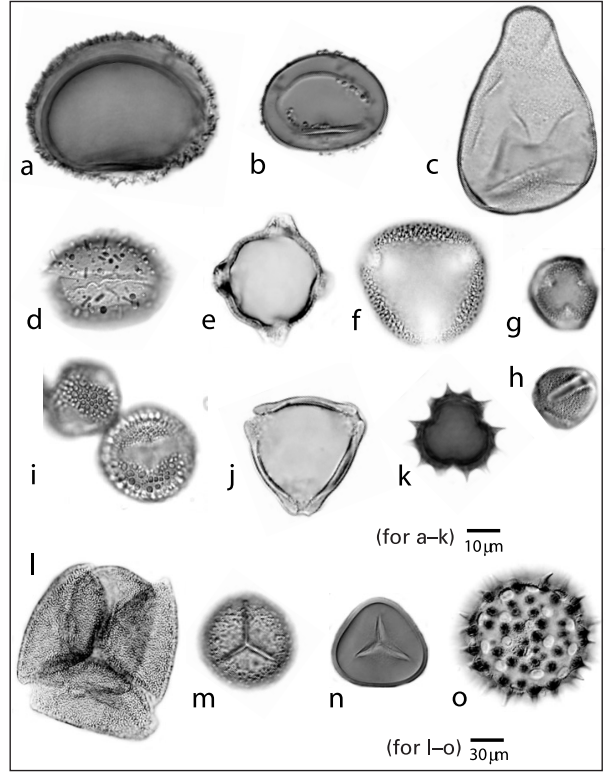

Figure 4. Pollen and spores of plants commonly found on Everglades tree islands and in adjacent marshes. a, Thelypteris kunthii (maiden fern); b, Blechnum serrulatum (swamp fern); c, Cladium jamaicense (sawgrass); $d$, Nymphaea odorata (waterlily); e, Bursera simaruba (gumbo limbo); f, Melothria pendula (creeping cucumber); $\mathrm{g}$ and h, Cephalanthus occidentalis (buttonbush); i, Ilex cassine (dahoon holly); j, Myrica cerifera (wax myrtle); k, Sphagneticola trilobata (Bay Biscayne creeping-oxeye); I, Annona glabra (pond apple); $\mathrm{m}$, Osmunda regalis (royal fern); $\mathrm{n}$, Acrostichum danaefolium (giant leather fern); o, Ipomoea sagittata (glades morning glory).

mid-20th century after construction of the C\&SF Project. At that time, holly pollen increased more than fourfold, indicating a substantial effect of water-management structures on plant communities of strand tree islands in the Loxahatchee NWR.

\section{Tree-Island Trends in the Central and Southern Everglades}

Fixed tree islands are prominent features of the central and southern Everglades and contrast with Loxahatchee strand islands in their teardrop shape, concentration of trees and shrubs at the north (upstream) end of the island, and development of a dense, shrubby tail downstream from the head. Analysis of numerous fixed tree islands shows that tree-island heads formed in shallow water depths on topographic highs. Before trees and shrubs were present, the heads were covered by sawgrass marshes surrounded by waterlily sloughs. Tree-island development began about 1,000-2,000 years ago, depending on location within the greater 

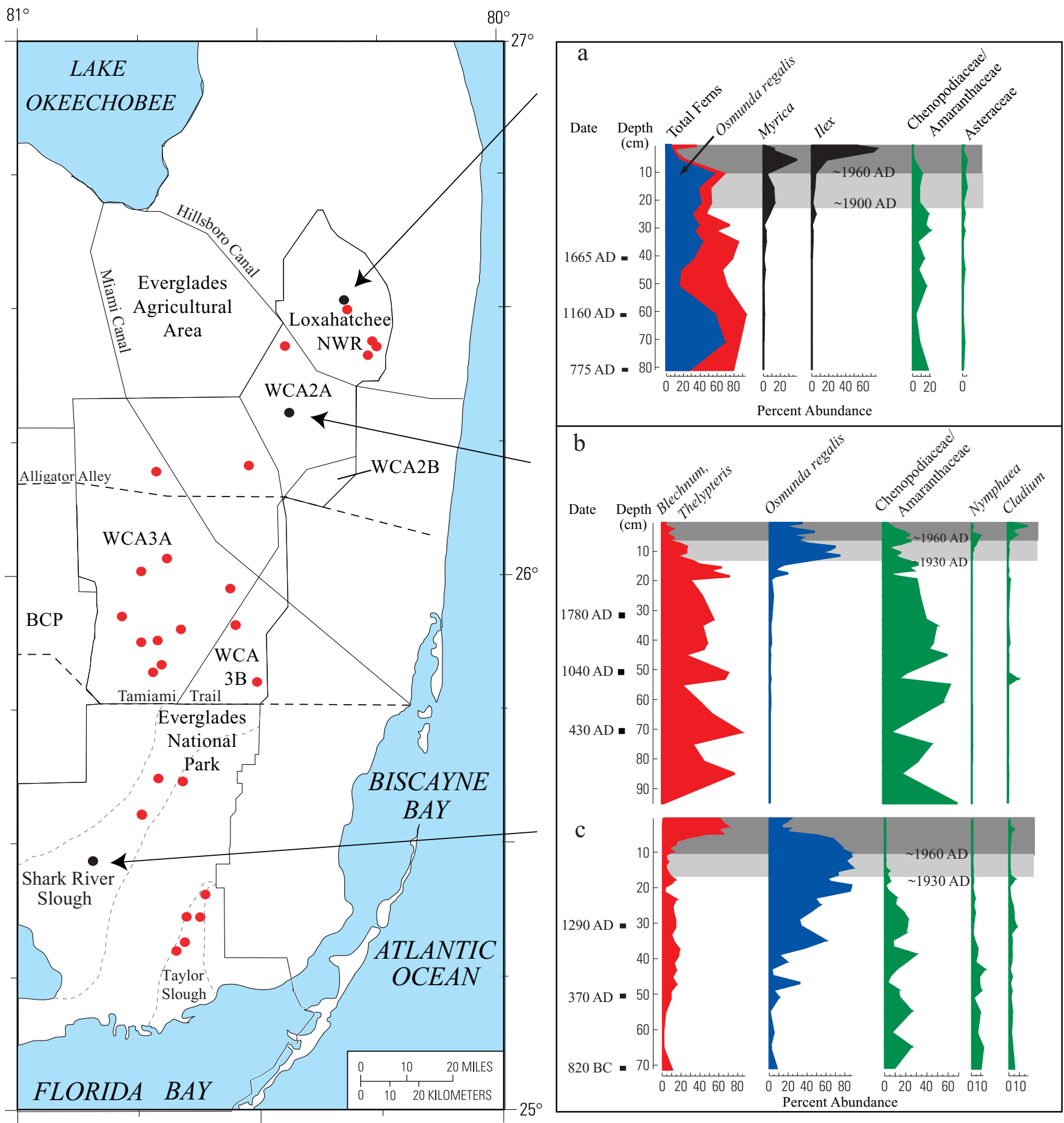

Figure 5. Location of 29 tree islands sampled in the Everglades between 1998 and 2002. Acronyms: BCP, Big Cypress National Preserve; NWR, National Wildlife Refuge; WCA, Water Conservation Area. Graphs a-c show percent abundance of pollen vs. depth (in centimeters) at three sites: a, Strand Island, Loxahatchee NWR; b, Treece's Island, WCA 2A; c, Manatee Hammock, Everglades National Park. Color coding in graphs: blue and red indicate fern abundance; blue = Osmunda regalis; red = other ferns; black = tree-island shrubs; green = marsh taxa.

Everglades ecosystem. Plant communities characteristic of mature tree-island vegetation developed 600-1,200 years ago.

After centuries of relative stability, hydrologic changes of the last 100 years have substantially altered the size and vegetational composition of fixed tree islands. In WCA 2A, water depths were kept at high levels for 13 consecutive years with no seasonal drawdowns. Sawgrass marshes and wet prairies were converted to deeper water sloughs, and many tree islands disappeared (fig. 6) (Light and Dineen, 1994). A sediment core collected in the modern tail of one drowned tree island, Treece's Island, illustrates some of the paleovegetational patterns (fig. 5b). Pollen assemblages indicate that the island developed at least 1,900 years ago; from then until the 20th century, taxa characteristic of relatively dry tree-island heads dominated the assemblages. Increased abundance of waterlily pollen after 1960 reflects the development of sloughs in deeper water while the tree-island community declined. After periodic drawdowns were incorporated into the water-management scheme in 1974, increased sawgrass pollen indicates a shift toward shallower water. These changes, and those in companion cores, reflect relatively rapid decrease in tree-island size and loss of trees due to sustained periods of deep 
water as well as the subsequent wetland response to hydrologic modifications to restore a more seasonal hydroperiod to the area.

In contrast to WCA 2A, sites within Everglades National Park were affected by reduced freshwater flow in the early 1930s. In a core collected in the tail of Manatee Hammock in Shark River Slough (fig. 5c), pollen assemblages indicate that mature tree-island vegetation was established about 500 years ago. Initial decreases in sheet flow around 1930 resulted in replacement of marsh and slough taxa by tree-island taxa. Additional flow reductions after completion of the Water Conservation Areas in the early 1960s are correlated with twofold to sixfold increases in abundance of ferns characteristic of drier conditions. These increases suggest that diversion of water from sheet flow during the 20th century resulted in expansion of tree-island size in Shark River Slough.

\section{Tree-Island Response to Everglades Restoration Strategies}

Fixed and strand tree islands of the Everglades are geologically old features that first developed in response to natural climatic and topographic controls 1,000-2,000 years ago (Willard and others, 2002). The distribution of these features was controlled by the topography of the underlying limestone; water depths were shallower than average over the high areas, which ultimately underwent sufficient seasonal drying for trees and shrubs to become established. Tree islands have been a distinctive component of the Everglades ecosystem for centuries to millennia, but altered water-management practices of the past century have changed their vegetational composition and size at varying scales.

Successful restoration and maintenance of tree islands require appropriate water depths and seasonally variable freshwater flow. Efforts to restore or create tree islands should focus on sites of drowned tree islands, because the requisite geologic and topographic conditions exist at those sites. Paleoecological evidence indicates that tree-island development took centuries; even with optimal hydrologic conditions, restoration of these features will not be rapid. Restoration goals should be set that are congruent with the pace of natural processes.

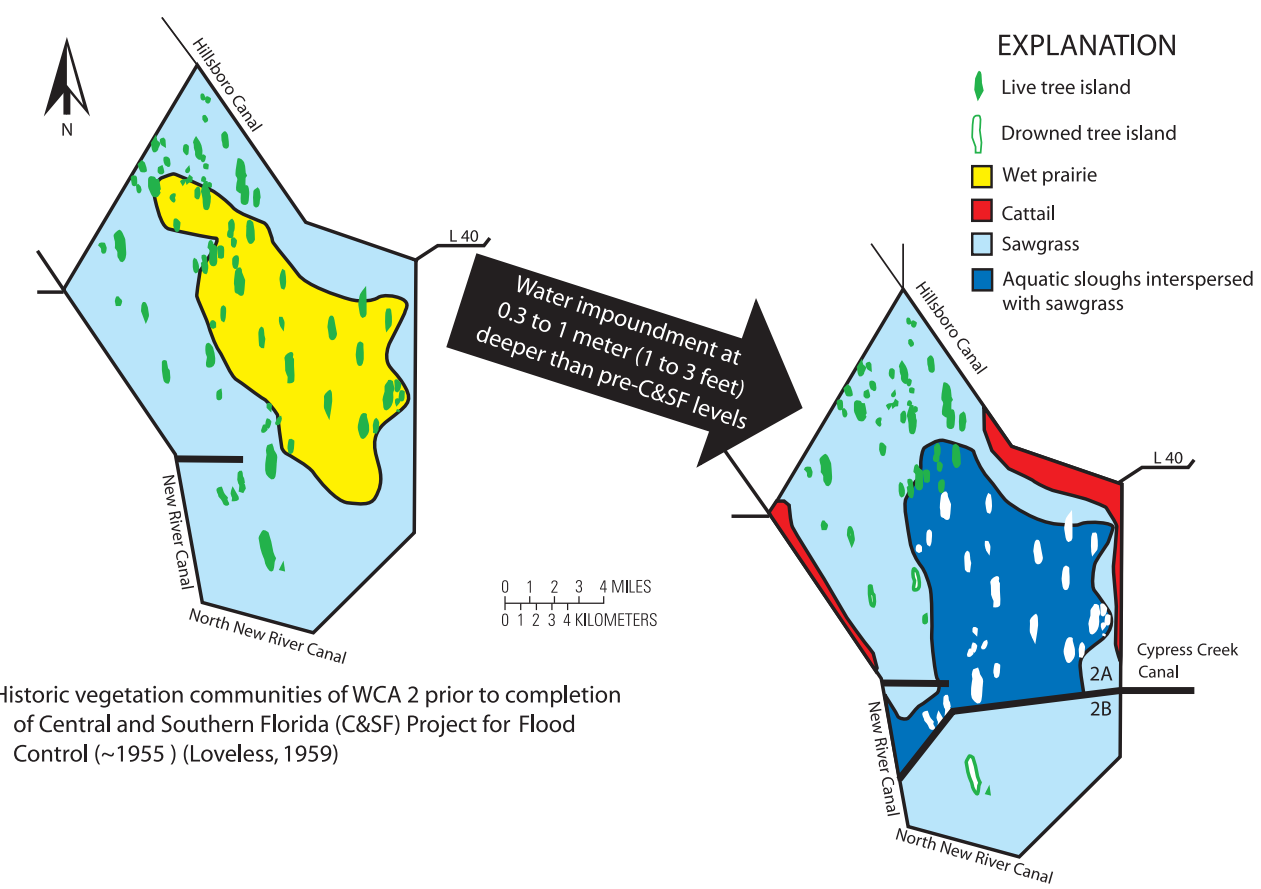

Dominant plant communities in WCA $2 \mathrm{~A}$ and $2 \mathrm{~B}$ after $\sim 13$ years of sustained high water levels without seasonal drawdowns ( 1973)

Figure 6. Comparison of distribution of plant communities in Water Conservation Area 2 before and after construction of the C\&SF Project. Modified from Worth (1988).

Although tree islands in some parts of the Everglades have disappeared because of overly long hydroperiods and deep water, those in other regions have become larger because of reduced water supplies. Therefore, restoration plans designed to improve Everglades tree-island health should incorporate regionally based performance measures; the plans would incorporate both differences in hydrology (past, present, and future) and inherent differences in species composition based on location within the greater Everglades ecosystem.

\section{By Debra A. Willard}

\section{References Cited}

Gleason, P.J., and Stone, Peter, 1994, Age, origin, and landscape evolution of the Everglades peatland, in Davis, S.M., and Ogden, J.C., eds., Everglades - The ecosystem and its restoration: Delray Beach, Fla., St. Lucie Press, p. 149-197.

Light, S.S., and Dineen, J.W., 1994, Water control in the Everglades - A historical perspective, in Davis, S.M., and Ogden, J.C., eds., Everglades - The ecosystem and its restoration: Delray Beach, Fla., St. Lucie Press, p. 47-84.

Loveless, C.M., 1959, A study of the vegetation of the Florida Everglades: Ecology, v. 40 , p. $1-9$.
Stone, P.A., Gleason, P.J., and Chmura, G.L., 2002, Bayhead tree islands on deep peats of the northeastern Everglades, in Sklar, F.H., and van der Valk, Arnold, eds., Tree islands of the Everglades: Dordrecht, The Netherlands, Kluwer Academic Publishers, p. 71-115.

Willard, D.A., Holmes, C.W., Korvela, M.S., Mason, Daniel, Murray, J.B., Orem, W.H., and Towles, D.T., 2002, Paleoecological insights on fixed tree island development in the Florida Everglades; I. Environmental controls, in Sklar, F.H., and van der Valk, Arnold, eds., Tree islands of the Everglades: Dordrecht, The Netherlands, Kluwer Academic Publishers, p. 117-151.

Willard, D.A., Weimer, L.M., and Riegel, W.L., 2001, Pollen assemblages as paleoenvironmental proxies in the Florida Everglades: Review of Palaeobotany and Palynology, v. 113, no. 4, p. 213-235.

Worth, D.F., 1988, Environmental response of WCA-2A to reduction in regulation schedule and marsh drawdown: South Florida Water Management District Technical Publication 88-2, 55 p.

\section{For further information, please contact:}

Debra A. Willard

U.S. Geological Survey

926A National Center

Reston, VA 20192

Telephone: 703-648-5320

E-mail: dwillard@usgs.gov 